\title{
Pengaruh Pemahaman, Kesadaran, Tarif Pajak dan Pelayanan Perpajakan Usaha Mikro, Kecil dan Menengah di Kabupaten Karawang
}

\author{
Ajeng Resti Fauzi*, Kholida Atiyatul Maula** \\ *Universitas Singaperbangsa, Karawang, Indonesia, restiajeng4@gmail.com \\ **Universitas Singaperbangsa, Karawang, Indonesia, kholida.maula@fe.unsika.ac.id
}

\begin{tabular}{l} 
ARTICLE INFO \\
\hline Article history: \\
Received 13 Oktoberr 2020 \\
Received in Revised 13 November 2020 \\
Accepted 30 November 2020 \\
\\
\hline Keywords: \\
Usaha Mikro, Kecil dan \\
Menengah (UMKM), \\
Pemahaman Perpajakan, \\
Kesadaran, Tarif Pajak, Pelayanan \\
Perpajakan dan Kepatuhan Wajib \\
Pajak
\end{tabular}

AKUISISI : Jurnal Akuntansi

Website : http://www.fe.ummetro.ac.id/ejournal/index.php/JA

This is an open access article distributed under the terms of the Creative Commons Attribution 4.0 International License, which permits unrestricted use, distribution, and reproduction in any medium, provided the original work is properly cited.

\section{ABSTRACT}

Tujuan penelitan ini adalah mengetahui pengaruh pemahaman, kesadaran, tarif pajak dan pelayanan perpajakan terhadap kepatuhan wajib pajak. Salah satu usaha untuk membantu perkembangan ekonomi yaitu dengan adanya UMKM yang ada di Indonesia. Pembangunan dan perkembangan negara akan semakin tumbuh jika pembiayaan negara berjalan dengan lancar. Salah satu usaha pemerintah agar pembiayaan negara berjalan dengan lancar yaitu pemerintah memerlukan sumber pembaiyaan negara yang memadai dalam pembangunan negara yang sedang dilakukan dengan cara membayar pajak. Populasi dalam penelian ini adalah UMKM yang termasuk UMKM Juara di Kabupaten Karawang periode tahun 2019 yang berjumlah 58 UMKM. Data dikumpulkan dengan cara menyebaran kuesioner kepada UMKM. Penelitian ini menggunakan teknik analisis linier berganda. Hasil pengujian secara parsial menunjukkan bahwa kesadaran pajak dan tarif berpengaruh terhadap kepatuhan wajib pajak, sedangkan pemahaman dan pelayanan perpajakan tidak berpengaruh terhadap kewajiban wajib pajak. Pada pengujian simultan hasil penelitian menunjukkan bahwa pemahaman, kesadaran, tarif pajak dan pelayanan perpajakan secara bersama-sama berpengaruh terhadap kepatuhan wajib pajak

\footnotetext{
* Corresponding author. Tel.: +0-000-000-0000 ; fax: +0-000-000-0000.
} E-mail address:

Peer review under responsibility of Akuisisi : Accounting Journal. 2477-2984 http://dx.doi.org/10.24217 


\section{PENDAHULUAN}

Indonesia merupakan negara berkembang yang mempunyai banyak usaha dan pembangunan disegala bidang yang mendukung perkembangan ekonomi agar semakin bertumbuh. Salah satu usaha untuk membantu perkembangan ekonomi tersebut yaitu dengan-adanya UMKM yang ada di Indonesia. UMKM adalah usaha yang mempunyai peranan penting dalam perekonomian negara Indonesia, baik dari sisi lapangan kerja, yang tercipta maupun dari jumlah sisi usahanya (Fahluzi dan Agustina, 2014). Pembangunan dan perkembangan negara akan semakin tumbuh jika pembiayaan negara berjalan dengan lancar. Salah satu usaha pemerintah agar pembiayaan negara berjalan dengan lancar yaitu pemerintah memerlukan sumber pembaiyaan negara yang memadai dalam pembangunan negara yang sedang dilakukan dengan cara membayar pajak. Potensi pajak yang bersumber dari UMKM saat ini belum bisa berjalan secara maksimal karena masih kurangnya sosialisasi, pemahaman atas perpajakan dan kesadaran akan pentingnya membayar pajak. Selain itu ada beberapa UMKM yang sudah mulai memahami tentang perpajakan dengan cukup baik namun masih terdapat keraguan untuk bersikap tertib dalam pembayaran pajak. Ada kekhawatiran bahwa ketertiban membayar pajak akan menuntut ketertiban dalam administrasi. Hal ini merupakan sesuatu yang ditakuti oleh para pelaku UMKM dan menyebabkan masih banyak UMKM yang tidak patuh denga kewajiban membayar pajaknya.

Masalah yang berkaitan dengan kepatuhan wajib pajak adalah permasalahan yang sedang menjadi perhatian pada sektor pajak. Saat ini tingkat kepatuhan wajib pajak di Indonesia masih sangat rendah. Tidak sebanding dengan pertumbuhan Usaha Mikro, Kecil dan Menengah yang semakin meningkat tetapi tidak diimbangi dengan kesadaran para pelaku UMKM dalam kepatuhannya membayar pajak (Indarwan dan Binekas, 2018).

Tarif pajak sebagai tolak ukur yang atas dasar perhitungam jumlah pajak yang wajib disetor. Penurunan tarif pajak UMKM dari $1 \%$ menjadi $0,5 \%$ adalah salah satu faktor yang mempengaruhi kepatuhan wajib pajak UMKM. Rendahnya pemahaman terhadap peraturan perpajakan juga menjadi faktor yang menyebabkan lemahnya kepatuhan wajib pajak itu sendiri. Rendahnya pemahaman ini bisa mempengaruhi wajib pajak dalam membayarkan pajaknya. Kesadaran wajib pajak yang dimiliki juga dapat menjadi faktor yang menyebabkan wajib pajak patuh terhadapat kewajiban pajaknyak. Karean kesadaran adalah unsur yang ada dalam diri manusia untuk memahami keadaan secara realita dan sikap untuk bertindak atau menyikapi sesuatu. Kesadaran perpajakan adalah kerelaan memenuhi kewajiban, yaitu wajib pajak rela untuk memberikan kontribusi berupa dana agar tercapainya pelaksanaan fungsi pemerintah yaitu dengan cara membayar kewajiban perpajakannya. Salah satu faktor yang menyebabkan rendahnya kepatuhan wajib pajak adalah para pegawai yang berada di kantor pajak seringkali tidak memberikan pelayanan secara maksimal. Pelayanan pajak merupakan 
pelayanan sosial yang diberikan pemerintah untuk memenuhi kebutuhan masyarakat ataupun dalam melaksanakan undang - undang dan tidak berorientasi pada laba atau profit. Dengan pelayanan yang baik, ramah, sopan, dan pelayanan yang prima maupun dapat memberikan kesan yang positif terhadap wajib pajak (Susmita dan Supadmi, 2016).

\section{Kerangka Pemikiran}

Sekarang ini fenomena yang terjadi adalah masih banyaknya wajib pajak yang masih belum memahami pemahaman dan pengetahuan perpajakan yang berlaku di Indonesia (Adiasa, 2013). Aspek pengetahuan dan pemahaman sangat penting karena akan mempengaruhi sikap wajib pajak terhadap kepatuhan wajib pajak dalam membayarkan pajaknya. Jika pemahaman perpajakan semakin membaik maka wajib pajak akan memenuhi kewajiban perpajakannya dengan benar.

Teori atribusi adalah teori yang sesuai untuk menjelaskan hipoesis ini. Pemahaman merupakan faktor internal dari teori atribusi karena pemahaman perpajakan merupakan dasar yang sangat penting untuk wajib pajak paham atas kewajibannya untuk membayar pajak. Jika wajib pajak paham atas perpajakan maka kepatuhan wajib pajak juga akan meningkat.

Menurut penelitian yang dilakukan Indarwan dan Binekas (2018) menyatakan bahwa pengetahuan perpajakan berpengaruh signifikan terhadap variabel kepatuahn wajib pajak. Sebanding dengan penelitian yang dilakukan Maula (2018) yang membuktikan bahwa pengetahuan dan pemahaman perpajakan berpengaruh positif dan signifikan terhadap penerapan pajak UMKM di KPP Pratama Cilacap. Sedangkan penelitian yang dilakukan oleh Azizah dkk (2016) adanya pengaruh negarif antara pemahaman denga kepatuhan membayar pajak.

H1 : Variabel independen Pemahaman Perpajakan berpengaruh terhadap variabel dependen Kepatuhan Wajib Pajak pada Usaha Mikro, Kecil dan Menengah (UMKM) di Kabupaten Karawang.

Kesadaran wajib pajak merupakan apa yang ada pada diri manusia dalam memahami realitas dan bagaimana cara bertindak atau menyikapi realitas. Apabila kesadaran wajib pajak tinggi akan perpengaruh terhadap kepatuhan wajib pajak. Maka seharusnya setiap wajib pajak memiliki kesadaran bahwa membayar pajak sangat penting bagi pertumbuhan negara. Kesadaran akan tumbuh pada diri wajib pajak jika wajib pajak mengerti tentang pentingnya membayar pajak. Kesadaran juga merupakan faktor internal yang ada dalam diri wajib pajak, maka teori atribusi juga sangat relevan untuk menjelaskan hipotesis ini. Wajib pajak harus memiliki kesadaran yang tinggi akan kewajibannya membayar pajak karena kesadaran akan mempengaruhi kepatuhan wajib pajak. Semakin tinggi kesadaran yang dimiliki wajib pajak maka akan menimbulkan pula kepatuhan wajib pajak yang tinggi. 
Sesuai penelitian yang dilakukan oleh Arisandi (2017) dan Hendri (2016) bahwa kesadaran berpengaruh signifikan terhadap kepatuhan wajib pajak, sebanding dengan penelitian yang dilakukan oleh Mahfud dkk (2017) hasil penelitiannya menunjukan bahwa kesadaran membayar pajak berpengaruh terhadap kepatuhan wajib pajak. Tetapi menurut Yusro dan Kiswanto (2014) kesadaran membayar pajak tidak berpengaruh terhadap kepatuhan wajib pajak.

H2 : Variebel independen kesadaran perbengaruh terhadap variabel dependen Kepatuhan Wajib Pajak pada Usaha Mikro, Kecil dan Menengah (UMKM) di Kabupaten Karawang

Tarif pajak pada awalnya diatur dalam Peraturan Pemerintah Nomor 46 Tahun 2013 dengan pengenaan tarif pajak sebesar $1 \%$ dari peredaran bruto. Kemudian pada tahun 2018 pemerintah melakukan perubahan tarif menjadi $0,5 \%$ dari peredaran bruto, perubahan tarif ini diatur dalam Peraturan Pemerintah Nomor 23 Tahun 2018. Perubahan tarif terjadi karena masih banyak wajib pajak yang merasa keberatan dengan tarif pajak yang dinilai terlalu memberatkan. Maka dari itu tarif pajak menjadi tolak ukur untuk menilai kepatuhan wajib pajak. Sesuai penelitian yang dilakukan oleh Cahyani dan Noviari (2019) bahwa tarif pajak perpengaruh signifikan terhadap kepatuhan wajib pajak. Selanjutnya ditemukan juga penelitian yang dilakukan Widodo (2019) bahwa penurunan tarif pajak secara parsial mempengaruhi kepatuhan wajib pajak UMKM di Kabupaten Rembang. Penelitian yang dilakukan Fitria dan Supriono (2019) hasil penelitian ini menunjukan bahwa tarif pajak memberikan pengaruh yang negatif.

H3 : Variabel independen Tarif Pajak berpengaruh terhadap variabel dependen Kepatuhan Wajib Pajak pada Usaha Mikro, Kecil dan Menengah (UMKM) di Kabupaten Karawang.

Secara umum pelayanan pajak atau bisa juga disebut pelayan fiskus merupakan petugas perpajakan. Ketika wajib pajak membayarkan pajaknya dikantor pajak akan menilai bagaimana wajib pajak mendapatkan pelayanan yang diberikan petugas pajak kepada wajib pajak. Jika wajib pajak mendapatkan pelayanan yang baik besar kemungkinan akan membuat wajib pajak semakin patuh untuk membayarkan pajaknya. Teori pembelajaran sosial relevan untuk menjelaskan hipotesis ini karena dalam teori pembelajaran sosial menejelaskan bahwa seseorang dapat belajar melalui pengamatan dan pengalaman langsung. Sikap yang diberikan langsung oleh petugas pajak kepada wajib pajak akan menimbulkan pengamatan dan pengalaman yang akan berdampak pada kepatuhan wajib pajak. Sesuai dengan penelitian yang dilakukan oleh Dawolo dan Suragih (2015) bahwa adanya pengaruh positif antara pelayanan pajak dengan kepatuhan pajak. Kemudian ditemukan juga penelitian yang dilakukan oleh Ariani Rubiatto Biettan (2018) menunjukan bahwa pelayanan aparat pajak berpengaruh signifikan terhadap kepatuhan wajib pajak UMKM. Penelitian yang dilakukan oleh Winerungan (2013) menyatakan bahwa pelayanan fiskus tidak berpengaruh terhadap kepatuhan wajib pajak. 
H4 : Variabel independen pelayanan perpajakan terhadap variabel dependen Kepatuhan Wajib Pajak pada Usaha Mikro, Kecil dan Menengah (UMKM) di Kabupaten Karawang

Aspek pengetahuan dan pemahaman sangat penting karena akan mempengaruhi sikap wajib pajak terhadap kepatuhan wajib pajak dalam membayarkan pajaknya. Jika pemahaman perpajakan semakin membaik maka wajib pajak akan memenuhi kewajiban perpajakannya dengan benar. Kesadaran wajib pajak merupakan apa yang ada pada diri manusia dalam memahami realitas dan bagaimana cara bertindak atau menyikapi realitas. Apabila kesadaran wajib pajak tinggi akan perpengaruh terhadap kepatuhan wajib pajak. Maka seharusnya setiap wajib pajak memiliki kesadaran bahwa membayar pajak sangat penting bagi pertumbuhan negara. Kesadaran akan tumbuh pada diri wajib pajak jika wajib pajak mengerti tentang pentingnya membayar pajak.

Tarif pajak pada awalnya diatur dalam Peraturan Pemerintah Nomor 46 Tahun 2013 dengan pengenaan tarif pajak sebesar $1 \%$ dari peredaran bruto. Kemudian pada tahun 2018 pemerintah melakukan perubahan tarif menjadi $0,5 \%$ dari peredaran bruto, perubahan tarif ini diatur dalam Peraturan Pemerintah Nomor 23 Tahun 2018. Perubahan tarif terjadi karena masih banyak wajib pajak yang merasa keberatan dengan tarif pajak yang dinilai terlalu memberatkan. Maka dari itu tarif pajak menjadi tolak ukur untuk menilai kepatuhan wajib pajak.

Secara umum pelayanan pajak atau bisa juga disebut pelayan fiskus merupakan petugas perpajakan. Ketika wajib pajak membayarkan pajaknya dikantor pajak akan menilai bagaimana wajib pajak mendapatkan pelayanan yang diberikan petugas pajak kepada wajib pajak. Jika wajib pajak mendapatkan pelayanan yang baik besar kemungkinan akan membuat wajib pajak semakin patuh untuk membayarkan pajaknya

H5 : Variabel independen pemahaman, kesadaran, tarif pajak dan pelayanan perpajakan terhadap variabel dependen Kepatuhan Wajib Pajak pada Usaha Mikro, Kecil dan Menengah (UMKM) di Kabupaten Karawang

\section{Gambar 1.Kerangka Berfikir}




METODE PENELITIAN

\section{Pengumpulan Data dan Sampel Penelitian}

Penelitian ini menggunakan metode penelitian yang mempunyai sifat deskripsif. Pendekatan yang digunakan dalam penelitian ini adalah pendekatan kuantitatif. Populasi pada penelitian ini adalah pelaku Usaha Mikro, Kecil dan Menengah yang terdaftar di KPP Karawang Utara pada tahun 2019 yaitu berjumlah 11.344 UMKM. Jumlah sampel yang diambil dari populasi yang ada pada penelitian ini adalah UMKM Juara yang berjumlah 58 UMKM sebagai sampel. Peneliti menetapkan beberapa kriteria sampel sebagai berikut :

1. UMKM yang termasuk UMKM Juara di Kabupaten Karawang

2. UMKM perseorangan yang memiliki hasil penjualan tahunan Rp. 300.000.000,00 dan memiliki kekayaan bersih (tidak termasuk tanah dan bangunan) paling banyak Rp. 50.000.000,00.

3. Responden merupakan UMKM yang termasuk wajib pajak Orang Pribadi

Teknik pengumpulan data pada penelitian ini adalah dengan cara menyebarkan kuesioner kepada wajib pajak UMKM.

\section{Variabel Penelitian}

Pada penelitian ini menggunakan 4 variabel independen dan 1 variabel dependen. Variabel independen yang digunakan adalah Pemahaman (X1), Kesadaran (X2), Tarif Pajak (X3) dan Pelayanan Perpajakan (X4). Variabale dependen yang digunakan adalah Kepatuhan Wajib Pajak (Y1).

\section{HASIL DAN PEMBAHASAN}

Penelitian ini menggunakan responden UMKM Juara di Kabupaten Karawang. Pengumpulan data dengan cara menyebarkan kuesioner secara langsung kepada responden. Hasil Pengumpulan data penelitian disajikan sebagai berikut :

Tabel 2. Hasil Pengumpulan Data dan Tingkat Pengembalian

\begin{tabular}{|c|c|}
\hline Jumlah Kuesioner Disebar & 58 \\
\hline Jumlah Kuesioner Kembali & 43 \\
\hline Jumlah Kuesioner Tidak Kembali & 15 \\
\hline Data Kuesioner Yang Digunakan & 43 \\
\hline Presentase Tingkat Pengembalian & $74,14 \%$ \\
\hline
\end{tabular}

Sumber: Hasil Data diolah, Peneliti (2020) 
Berdasarkan tabel diatas diketahui bahwa dari 58 kuesioner yang disebar, sebanyak 43 kuesioner atau sebesar 74,14\% kuesioner yang kembali dan 15 kuesioner tidak kembali, artinya data yang digunakan dalam penelitian ini adalah sebanyak 43.

Berikut ini karakteristik responden UMKM Juara berdasarkan kategori jenis kelamin dan dan jenis usaha :

Tabel 3. Karakteristik Data Responden

\begin{tabular}{|c|c|c|c|}
\hline Jenis Kategori & Keterangan & Jumlah & Presentase \\
\hline Jenis Kelamin & Laki- Laki & 13 & $40,7 \%$ \\
& Perempuan & 30 & $59,3 \%$ \\
\hline Jenis Usaha & Makanan & 29 & $73,6 \%$ \\
& Minuman & 5 & $8,5 \%$ \\
& Kerajinan & 6 & $10,2 \%$ \\
& Konveksi & 2 & $3,4 \%$ \\
& Meubeul & 1 & $1,7 \%$ \\
\hline
\end{tabular}

Sumber: Hasil Data diolah SPSS, Peneliti (2020)

Berdasarkan tabel diatas, menunjukkan bahwa responden penelitian mayoritas Perempuan sebesar 59,3\% sedangkan Laki - Laki sebesar 40,7\%. Karakteristik responden berdasarkan Jenis Usaha untuk lulusan Makanan sebesar 73,6\%, Minuman sebesar 8,5\%, Kerajinan sebesar 10,2\%, Konveksi sebesar 3,4\% dan Mebeul sebesar1,7\%.

\section{Analisis Deskriptif}

Analisis deskriptif dalam penelitian ini yaitu terdiri dari: nilai mean (rata- rata), nilai minimum (terendah), nilai maksimum (tertinggi), dan standar deviasi pada setiap variabel. Tujuan dari analisis deskriptif yaitu untuk menggambarkan suatu data secara statistik.

Tabel 4.Hasil Analisis Deskriptif

\begin{tabular}{|c|c|c|c|c|c|}
\hline & $\mathbf{N}$ & Min & Max & Mean & Std Deviation \\
\hline $\mathrm{X} 1$ & 43 & 26 & 35 & 30,86 & 2,336 \\
\hline $\mathrm{X} 2$ & 43 & 20 & 30 & 26,09 & 2,338 \\
\hline $\mathrm{X} 3$ & 43 & 10 & 18 & 13,14 & 2,054 \\
\hline $\mathrm{X} 4$ & 43 & 22 & 30 & 26,44 & 2,302 \\
\hline $\mathrm{Y}$ & 43 & 19 & 25 & 22,07 & 1,993 \\
\hline
\end{tabular}

Sumber: Hasil Data diolah SPSS, Peneliti (2020) 
Berdasarkan hasil data diatas, diketahui bahwa nilai $\mathrm{N}$ sdadssebanyak 43 artinya data yang digunakan dalam penelitian ini sebanyak 43 lembar keusioner data yang berasal dari wajib pajak UMKM Juara Kabupaten Karawang. Pemahaman Perpajakan berdasarkan hasil pengeolahan data tersebut, diperoleh nilai rata-rata sebesar 30,86 dengan nilai standar deviasi 2,336. Hal tersebut menunjukkan bahwa nilai standar deviasi lebih kecil dibandingkan nilai rata-rata, artinya dalam penelitian data berdistribusi normal. Serta untuk nilai minimum sebesar 26 dan nilai maksimum sebesar 35. Kesadaran Perpajakan berdasarkan hasil pengolahan data tersebut, diperoleh nilai rata-rata sebesar 26,09 dengan nilai standar deviasi 2,338. Hal tersebut menunjukkan bahwa nilai standar deviasi lebih kecil dibandingkan nilai rata-rata, artinya dalam penelitian data berdistribusi normal. Serta untuk nilai minimum sebesar 20 dan nilai maksimum sebesar 30. Tarif Pajak berdasarkan hasil pengolaham data tersebut, diperoleh nilai rata-rata sebesar 13,14 dengan nilai standar deviasi 2,054. Hal tersebut menunjukkan bahwa nilai standar deviasi lebih kecil dibandingkan nilai rata-rata, artinya dalam penelitian data berdistribusi normal. Serta untuk nilai minimum sebesar 10 dan nilai maksimum sebesar 18. Pelayanan Perpajakan berdasarkan hasil pengolaham data tersebut, diperoleh nilai rata-rata sebesar 26,44 dengan nilai standar deviasi 2,302. Hal tersebut menunjukkan bahwa nilai standar deviasi lebih kecil dibandingkan nilai rata-rata, artinya dalam penelitian data berdistribusi normal. Serta untuk nilai minimum sebesar 22 dan nilai maksimum sebesar 30. Kepatuhan Wajib Pajak UMKM berdasarkan hasil pengolahan data tersebut, diperoleh nilai rata-rata sebesar 22,07 dengan nilai standar deviasi 1,993. Hal tersebut menunjukkan bahwa nilai standar deviasi lebih kecil dibandingkan nilai rata-rata, artinya dalam penelitian data berdistribusi normal. Serta untuk nilai minimum sebesar 19 dan nilai maksimum sebesar 25.

\section{Uji Validitas}

Pengujian ini dilakukan dengan menggunakan Pearson Product Moment. Pedoman suatu model dikatakan valid jika tingkat signifikansi dibawah 0,05 dengan uji 2 sisi dan jumlah data $(\mathrm{n})=$ 43, maka didapat $r$ tabelnya sebesar 0,300. Hasil uji validitas instrumen Pemahaman (X1) dari 7 (tujuh) butir pertanyaan, dan dari 7 (tujuh) pertanyaan dinyatakan valid karena angka yang diperoleh dari perhitungan lebih besar dari $r$ tabel. 
Tabel 5. Hasil Validitas Untuk Instrumen Pemahaman

\begin{tabular}{|c|c|c|c|c|}
\hline Pertanyaan & Pearson Product Moment & $\mathrm{r}$-tabel 5\%(43) & Sig. & Ket \\
\hline Item 1 & 0,753 & 0,300 & & \\
\hline Item 2 & 0,599 & 0,300 & 0 & Valid \\
\hline Item 3 & 0,727 & 0,300 & 0 & Valid \\
\hline Item 4 & 0,341 & 0,300 & 0 & Valid \\
\hline Item 5 & 0,445 & 0,300 & 0 & Valid \\
\hline Item 6 & 0,658 & 0,300 & 0 & Valid \\
\hline Item 7 & 0,725 & 0,300 & & Valid \\
& & & 0 & Valid \\
\hline
\end{tabular}

Sumber: Hasil Data diolah SPSS, Peneliti (2020)

Hasil uji validitas instrumen Kesadaran (X2) dari 6 (enam) butir pertanyaan, dan dari 6 (enam) pertanyaan dinyatakan valid karena angka yang diperoleh dari perhitungan lebih besar dari $r$ tabel.

Tabel 6. Hasil Validitas Untuk Instrumen Kesadaran

\begin{tabular}{|c|c|c|c|l|}
\hline Pertanyaan & Pearson Product Moment & r-tabel 5\%(43) & Sig. & Ket \\
\hline Item 1 & 0,667 & 0,300 & 0 & Valid \\
\hline Item 2 & 0,753 & 0,300 & 0 & Valid \\
\hline Item 3 & 0,768 & 0,300 & 0 & Valid \\
\hline Item 4 & 0,606 & 0,300 & 0 & Valid \\
\hline Item 5 & 0,676 & 0,300 & 0 & Valid \\
\hline Item 6 & 0,708 & 0,300 & 0 & Valid \\
\hline
\end{tabular}

Sumber: Hasil Data diolah SPSS, Peneliti (2020)

Hasil uji validitas instrumen Tarif Pajak (X3) dari 4 (empat) butir pertanyaan, dan dari 4 (empat) pertanyaan dinyatakan valid karena angka yang diperoleh dari perhitungan lebih besar dari $r$ tabel. 
Tabel 7. Hasil Validitas Untuk Instrumen Tarif Pajak

\begin{tabular}{|l|c|c|c|l|}
\hline Pertanyaan & Pearson Product Moment & r-tabel 5\%(43) & Sig. & Ket \\
\hline Item 1 & 0,640 & 0,300 & 0 & Valid \\
\hline Item 2 & 0,645 & 0,300 & 0 & Valid \\
\hline Item 3 & 0,787 & 0,300 & 0 & Valid \\
\hline Item 4 & 0,833 & 0,300 & 0 & Valid \\
\hline
\end{tabular}

Sumber: Hasil Data diolah SPSS, Peneliti (2020)

Hasil uji validitas instrumen Pelayanan Perpajakan (X4) dari 6 (enam) butir pertanyaan, dan dari 6 (enam) pertanyaan dinyatakan valid karena angka yang diperoleh dari perhitungan lebih besar dari $r$ tabel.

Tabel 8. Hasil Validitas Untuk Instrumen Pelayanan Perpajakan

\begin{tabular}{|l|c|c|c|l|}
\hline Pertanyaan & Pearson Product Moment & r-tabel 5\%(43) & Sig. & Ket \\
\hline Item 1 & 0,622 & 0,300 & 0 & Valid \\
\hline Item 2 & 0,816 & 0,300 & 0 & Valid \\
\hline Item 3 & 0,623 & 0,300 & 0 & Valid \\
\hline Item 4 & 0,690 & 0,300 & 0 & Valid \\
\hline Item 5 & 0,776 & 0,300 & 0 & Valid \\
\hline Item 6 & 0,713 & 0,300 & 0 & Valid \\
\hline
\end{tabular}

Sumber: Hasil Data diolah SPSS, Peneliti (2020)

Hasil uji validitas instrumen Pelayanan Kepatuhan Wajib Pajak (Y) dari 5 (enam) butir pertanyaan, dan dari 5 (lima) pertanyaan dinyatakan valid karena angka yang diperoleh dari perhitungan lebih besar dari $r$ tabel.

Tabel 9.Hasil Validitas Untuk Instrumen Kepatuhan Wajib

\begin{tabular}{|l|c|c|c|c|}
\hline Pertanyaan & Pearson ProductMoment & $\mathrm{r}$-tabel 5\%(43) & Sig. & Ket \\
\hline Item 1 & 0,670 & 0,300 & 0 & Valid \\
\hline Item 2 & 0,740 & 0,300 & 0 & Valid \\
\hline Item 3 & 0,698 & 0,300 & 0 & Valid \\
\hline Item 4 & 0,816 & 0,300 & 0 & Valid \\
\hline Item 5 & 0,740 & 0,300 & 0 & Valid \\
\hline
\end{tabular}




\section{Uji Reabilitas}

Tabel 10. Hasil Uji Reabilitas

\begin{tabular}{|l|c|c|}
\hline \multicolumn{1}{|c|}{ Instrumen } & Cronbach's Alpha & Keterangan \\
\hline Pemahaman Perpajakan & 0,716 & Reliable \\
\hline Kesadaran Perpajakan & 0,788 & Reliable \\
\hline Tarif Pajak & 0,706 & Reliable \\
\hline Pelayanan Perpajakan & 0,803 & Reliable \\
\hline Kepatuhan Wajib Pajak & 0,785 & Reliable \\
\hline
\end{tabular}

Sumber: Hasil Data diolah SPSS, Peneliti (2020)

Berdasarkan tabel diatas dapat dilihat bahwa variabel Pemahaman Perpajakan dapat dikatakan reliable karena Cronbach's Alpha diatas 0,60 yaitu 0,716. Variabel Kesadaran dapat dikatakan reliable karena Cronbach's Alpha diatas 0,60 yaitu 0,788. Variabel independen lainnya yaitu Tarif Pajak juga dapat dikatakan reliable karena Cronbach's Alpha diatas 0,60 yaitu 0,706 dan variabel Pelayanan Perpajakan juga dapa dikatakan reliable karena Cronbach's Alpha diatas 0,06 yaitu 0,803. Sedangkan untuk variabel dependennya yaitu Kepatuhan Wajib Pajak UMKM dapat dikatakan reliable karena Cronbach's Alpha diatas 0,60 yaitu 0,785 .

\section{Uji Regresi Linier Berganda}

Dalam penelitian ini uji regresi linier berganda dilakukan untuk mengetahui pengaruh antara Pemahaman, Kesadaran, Tarif Pajak dan Pelayanan Perpajakan terhadap Kepatuhan Wajib Pajak. Berikut pengolahan data menggunakan bantuan SPSS 24. Selengkapnya dapat dilihat pada tabel 4.10 sebagai berikut :

Tabel 11.Uji Regresi Linier Berganda

\begin{tabular}{|c|c|c|c|c|}
\hline \multicolumn{2}{|c|}{ Model } & \multicolumn{2}{c|}{ Unstandardized Coefficients } & $\begin{array}{c}\text { Standardized } \\
\text { Coefficients }\end{array}$ \\
\cline { 2 - 5 } \multicolumn{2}{|c|}{} & B & Std.Error & Beta \\
\hline \multirow{2}{*2}{1} & (Constant) & 9.514 & 3.604 & 0.132 \\
\cline { 2 - 5 } & Total Pemahaman & 0.112 & 0.140 & 0.613 \\
\cline { 2 - 5 } & Total Kesadaran & 0.523 & 0.157 & \\
\hline
\end{tabular}




\begin{tabular}{|l|l|c|c|c|}
\hline \multirow{2}{*}{ Total Tarif Pajak } & -0.380 & 0.139 & -0.392 \\
\cline { 2 - 5 } & Total Pelayanan & 0.017 & 0.140 & 0.020 \\
\hline
\end{tabular}

Sumber: Hasil data diolah SPSS, Peneliti (2020)

Berdasarkan perhitungan regresi linier berganda pada tabel 4.6 dapat diketahui hubungan antara variabel dependen dan independen yang dapat dijelaskan sebagai berikut:

$$
\mathrm{Y}=9,514+0,112 \mathrm{X} 1+0,523 \mathrm{X} 2-0,380 \mathrm{X} 3+0,017
$$

\section{Pengujian Hipotesis}

Uji Hipotesis Secara Parsial ( Uji t )

Pengujian hipotesis secara parsial dilakukan untuk mengetahui variabel yang berpengaruh signifikan secara parsial dilakukan dengan pengujian koefisien regresi dengan menggunakan Uji t.

Tabel 12. Hasil Uji Hipotesis Secara Parsial

\begin{tabular}{|l|c|c|c|c|c|}
\hline \multicolumn{5}{|c|}{ Coefficient } \\
\hline \multicolumn{2}{|c|}{ Model } & Standardized Coefficients Beta & $t$ & Sig. \\
\hline 1. Cons & 9,514 & 3,604 & & 2,640 & 0,012 \\
\hline X1 & 0,112 & 0,140 & 0,132 & 0,799 & 0,429 \\
\hline X2 & 0,523 & 0,157 & 0,613 & 3,325 & 0,002 \\
\hline X3 & -0380 & 0,139 & $-0,392$ & $-2,736$ & 0,009 \\
\hline X4 & 0,017 & 0,140 & 0,020 & 0,123 & 0,903 \\
\hline
\end{tabular}

Sumber: Hasil data diolah SPSS, Peneliti (2020)

a. Pengaruh Pemahaman Perpajakan terhadap Kepatuhan Wajib Pajak UMKM

Berdasarkan hasil pengujian diperoleh nilai thitung sebesar 2,024. Jika dibandingkan dengan nilai ttabel yaitu 0,799 sehingga t-hitung < t-tabel. Dan nilai signifikansi sebesar 0,429 lebih besar dari 0,05. Dengan demikian, dapat disimpulkan bahwa tidak terdapat pengaruh antara Pemahaman Perpajakan terhadap Kepatuhan Wajib Pajak UMKM

b. Pengaruh Kesadaran terhadap Kepatuhan Wajib Pajak UMKM

Berdasarkan hasil pengujian diperoleh nilai hitung sebesar 2,024. Jika dibandingkan dengan nilai ttabel yaitu $-3,325$ sehingga t-hitung $>$ t-tabel. Sehingga nilai signifikansi sebesar 0,002 lebih kecil 
dari 0,05. Dengan demikian, dapat disimpulkan bahwa terdapat pengaruh antara Kesadaran terhadap Kepatuhan Wajib Pajak UMKM.

c. Pengaruh Tarif Pajak terhadap Kepatuhan WajibPajak UMKM

Berdasarkan hasil pengujian diperoleh nilai hitung sebesar 2,024. Jika dibandingkan dengan nilai ttabel yaitu $-2,736$ sehingga t-hitung $>$ t-tabel. Sehingga nilai signifikansi sebesar 0,009 lebih besar dari 0,05. Dengan demikian, dapat disimpulkan bahwa terdapat pengaruh antara Tarif Pajak terhadap Kepatuhan Wajib Pajak UMKM.

d. Pengaruh Pelayanan terhadap Kepatuhan Wajib Pajak UMKM

Berdasarkan hasil pengujian diperoleh nilai t-hitung sebesar 2,024. Jika dibandingkan dengan nilai t-tabel yaitu 0,123 sehingga t-hitung $<$ t-tabel. Sehingga nilai signifikansi sebesar 0,462 lebih besar dari 0,05. Dengan demikian, dapat disimpulkan bahwa tidak terdapat pengaruh antara Pelayanan Perpajakan terhadap Kepatuhan Wajib Pajak UMKM.

Uji Hipotesis Secara Simultan ( Uji f)

Tabel 13. Hasil Uji Hipotesis Secara Simultan

Anova

\begin{tabular}{|l|c|c|c|l|l|}
\hline Model & Sun Of Square & df & Mean Square & f & Sig. \\
\hline Regression & 74.028 & 4 & 18.507 & 7.581 & 0.000 \\
Residual & 92.763 & 38 & 2.441 & & \\
Total & 166.791 & 42 & & & \\
\hline
\end{tabular}

a. Dependent Variable: Total Kepatuhan

b. Predictors: (Constant), Total Pelayanan, Total Tarif Pajak, Total Pemahaman, Total Kesadaran Sumber: Hasil data diolah SPSS, Peneliti (2020)

Berdasarkan hasil pengujian diatas, dapat diketahui nilai f-hitung sebesar 7,581. Adapun nilai f-tabel pada tingkat signifikansi $5 \%$ dan derajat kebebasan df1 $=4$ dan df $2=53$, maka f-tabel didapat $(4: 38)=2,62$. Nilai F-hitung dengan F-tabel selanjutnya dibandingkan, sehingga diperoleh nilai 7,5812>2,62 artinya nilai F-hitung lebih besar dari F-tabel. Nilai signifikansi sebesar 0,000 disimpulkan adanya pengaruh secara simultan Pemahaman Perpajakan, Kesadaran, Tarif Pajak dan Pelayanan Perpajakan. 
Tabel 14. Koefisien Determinasi

\begin{tabular}{|c|c|c|c|c|}
\hline Model & R & R Square & Adjusted R Square & Std. Error Of the Estimate \\
\hline 1 & 0,666 & 0,444 & 0,385 & 1.562 \\
\hline
\end{tabular}

a. Predictors: (Constant), Total Pelayanan,

Total Tarif Pajak, Total Pemahaman, Total Kesadaran

b. Dependent Variable: Total Kepatuhan

Hasil Analisis Koefisien Determinasi

Sumber: Hasil data diolah SPSS, Peneliti (2020)

Dari hasil pengolahan data diatas, dapat dilihat bahwa nilai koefisien determinasi atau R2 sebesar 0,385 atau sebesar 38,5\%. Hal ini menunjukkan bahwa variabel yang diteliti yaitu Pemahaman Peraturan Perpajakan, Kesadaran, Tarif Pajak dan Pelayanan Perpajakan berpengaruh sebesar 38,5\% terhadap Kepatuhan Wajib Pajak UMKM di Kabupaten Karawang . Sedangkan sisanya $61,5 \%$ dipengaruhi oleh variabel yang tidak diteliti dalam penelitian ini atau variabel pengganggu.

\section{KESIMPULAN}

Dalam penelitian ini ditujukan untuk menganalisis tentang Kepatuhan Wajib Pajak. Variabel penelitian yang digunakan adalah variabel dependen, yaitu Kepatuhan Wajib Pajak. Sedangkan variabel independen yang digunakan adalah Pemahaman Perpajakan, Kesadaran, Tarif Pajak dan Pelayanan Perpajakan. Berdasarkan tabel determinasi atau R2 sebesar 0,385 atau sebesar 38,5\%. Hal ini menunjukkan bahwa variabel yang diteliti yaitu Pemahaman Peraturan Perpajakan, Kesadaran, Tarif Pajak dan Pelayanan Perpajakan berpengaruh sebesar 38,5\% terhadap Kepatuhan Wajib Pajak UMKM di Kabupaten Karawang. Berarti masih banyak faktor - faktor lain yang dapat mempengaruhi Kepatuhan Wajib Pajak.

Berdasarkan penelitian dan pembahasan yang dilakukan penulis mengenai Pengaruh Pemahaman Perpajakan, Kesadaran, Tarif Pajak dan Pelayanan Perpajakan terhadap Kepatuhan Wajib Pajak UMKM di Kabupaten Karawang tahun 2020 yang telah dilakukan dapat diambil kesimpulan sebagai berikut :

1. Pemahaman Perpajakan tidak berpengaruh terhadap Kepatuhan Wajib Pajak UMKM di Kabupaten Karawang.

2. Kesadaran berpengaruh terhadap Kepatuhan Wajib Pajak UMKM di Kabupaten Karawang.

3. Tarif Pajak berpengaruh terhadap Kepatuhan Wajib Pajak UMKM di Kabupaten Karawang. 
4. Pelayanan Perpajakan tidak berpengaruh terhadap Kepatuhan Wajib Pajak UMKM di Kabupaten Karawang.

5. Pemahaman Perpajakan, Kesadaran, Tarif Pajak dan Pelayanan Perpajakan berpengaruh terhadap Kepatuhan Wajib Pajak UMKM di Kabupaten Karawang.

\section{DAFTAR PUSTAKA}

Adiasa, Nirawan. 2013. Pengaruh Pemahaman Peraturan Pajak Terhadap Kepatuhan Wajib Pajak Dengan Preferensi Resiko Sebagai Variabel Moderating. Skripsi. Universitas Negeri Semarang

Ariani, Marieta dan Rubiatto Biettan. 2018. Pengaruh Pelayanan Fiskus Terhadap Kepatuhan Wajib Pajak Dengan Variabel Intervening Kepuasan Wajib Pajak. Jurnal Informasi Perpajakan, Akuntansi dan Keuangan Publik Vol. 13 No.1 1 Januari 2018. Universitas Trisakti. ISSN: 2685-6441 (Online) 1907-7769 (Paper).

Azizah, Istiqomah Nur, Siti Nurlaela, dan Anita Wijayanti. 2016. Faktor - faktor yang Mempengaruhi Kemauan Membayar Pajak Wajib Pajak Orang Pribadi yang Melakukan Pekerjaan Bebas. Jurusan Akuntnasi. Fakultas Ekonomi dan Bisnis. Universitas Islam Batik Surakarta. ISSN: $2337-4349$

Cahyani, Luh Putu Gita dan Naniek Noviari. 2019. Pengaruh Tarif Pajak, Pemahaman Perpajakan, dan Sanksi Perpajakan Terhadap Kepatuhan Wajib Pajak UMKM. E- Jurnal Akuntansi Universitas Udayana Vol.26.3. ISSN : 2320-8556.

Dawolo, Steven Briantoro dan Joana L Saragih. 2015. Pengaruh Sanksi Pajak, Kualitas Pelayanan Fiskus, Kesadaran Perpajakan Terhadap Kepatuhan Wajib Pajak Orang Pribadi di KPP Pratama Medan Petisah. JRAK Vol. 1 No.2, September 2015. ISSN : 2443-1079.

Fahluzy, Septiani Fahmi dan Linda Agustina. 2014. Faktor - Faktor yang Mempengaruhi Kepatuhan Membayar Pajak UMKM di Kabupaten Kendal. Jurusan Akuntansi. Fakultas Ekonomi. Universitas Negeri Semarang. ISSN : 2252-6765.

Fitri, Pipit Anisa dan Edy Sipriono. 2019. Pengaruh Pemahaman Peraturan Perpajakan, Persepsi Tarif Pajak, dan Keadilan Perpajakan Terhadap Kepatuhan Wajib Pajak. Journal of Ekonomic and Banking Vol.1 No.1. ISSN: 2685-3698.

Indrawan, Rizki dan Bani Binekas. 2018. Pemahaman Pajak dan Pengetahuan Pajak Terhadap Kepatuhan Wajib Pajak UKM. Jurusan Akuntansi. Program Studi Akuntansi S1. Fakultas Ekonomi dan Bisnis. Universitas Jendral Achmad Yani. ISSN : 2541-061X (Online) ISSN : 2338-1507 (Print)

Mahfud, Muhammad Arfan dan Syukriy Abdullah. 2017. Pengaruh Pemahaman Peraturan Perpajakan, Kesadaran Membayar Pajak dan Kualitas Pelayanan Perpajakan Terhadap Kepatuhan Wajib Pajak Badan (Studi Empiris Pada Koprasi di Kota Banda Aceh). Magister Akuntansi Program Pasca Sarjana Universitas Syiah Kuala Banda Aceh. ISSN : 2302-0164. 
Hendri, Nedi. (2016). Faktor-faktor yang Mempengaruhi Kepatuhan Wajib Pajak dalam Membayar Pajak pada UMKM di Kota Metro. Jurnal AKUISISI. Vol.12 (1) April 2016

Nelsi Arisandi. 2017. Pengaruh Pemahaman Wajib Pajak, Kesadaran Wajib Pajak, dan Sanksi Pajak Terhadap Kepatuhan Wajib Pajak Orang Pribadi Yang Melakukan Kegiatan Bisnis Online di Pekanbaru. Jurnal Imiah Ekonomi dan Bisnis Vol.14 No.1 Maret 2017. Universitas Islam Sutan Syarif Kasim Riau. EISSN : 2442-981 ISSN : 1829-9822.

Peraturan Pemerintah Nomor 46 Tahun 2013 tentang Tarif Pajak

Peraturan Pemerintah Nomor 23 Tahun 2018 tentang Tarif Pajak

Supadmi, Ni Luh. 2009. Meningkatkan Kepatuhan Wajib Pajak Melalui Kualitas Pelayanan. Jurnal Akuntansi \& Bisnis, Vol. 4, No. 2, Hal:1-14.

Susmita, Putu Rara dan Ni Luh Supadmi. 2016. Pengaruh Kualitas Pelayanan, Sanksi Perpajakan, Biaya Kepatuhan Pajak dan Penerapan E-Filling pada Kepatuhan Wajib Pajak. E-Jurnal Akuntnasi Universitas Udayana 14.2. Februari 2016. ISSN : 2302-8556.

Widodo, Agus. 2019. Pengaruh Penurunan Tarif Pajak PPh Final dan Sanksi Pajak Terhadap Kepatuhan Wajib Pajak UMKM di Kabupaten Rembang. JAB Vol.5 No.1, Juni 2019. Sekolah Tinggi Ilmu Ekonomi YPPI Rembang. ISSN: 2502-3497

Winerungan, Oktaviane Lidya Winerungan. 2013. Sosialisasi Perpajakan, Pelayanan Fiskus dan Sanksi Perpajakan tehadap Kepatuhan WPOP di KPP Manado dan KPP Bitung. Jurnal EMBA Vol.1 No.3 September 2013. Universitas Sam Ratulangi Manado. ISSN : 2303-1174.

Yusro, Henry Wachdiatul dan Kiswanto. 2014. Pengaruh Tarif Pajak, Mekanisme Pembayaran Pajak, dan Kesadaran Membayar Pajak Terhadap Kepatuhan Wajib Pajak UMKM di Kabupaten Jepara. Jurusan Akuntansi. Fakultas Ekonomi. Universitas Negeri Semarang. ISSN : 22526765. 